Pesq. Vet. Bras. 35(11):906-912, novembro 2015

DOI: $10.1590 / \mathrm{S} 0100-736 \mathrm{X} 2015001100006$

\title{
Immunodetection of myeloid and plasmacytoid dendritic cells in mammary carcinomas of female $\operatorname{dog} \mathbf{s}^{1}$
}

\author{
Mayara C. Rosolem², Rosemeri O. Vasconcelos ${ }^{2 *}$, Eduardo Garrido ${ }^{3}$, Thaís L.L. \\ Castanheira $^{4}$, Pamela R.R. Moreira ${ }^{2}$, Geórgia M. Magalhães ${ }^{5}$, Daniela B. Rozza ${ }^{6}$ \\ and Salvador B. Ramos ${ }^{7}$
}

\begin{abstract}
Rosolem M.C., Vasconcelos R.O., Garrido E., Castanheira T.L.L., Moreira P.R.R., Magalhães G.M., Rozza D.B. \& Ramos S.B. 2015. Immunodetection of myeloid and plasmacytoid dendritic cells in mammary carcinomas of female dogs. Pesquisa Veterinária Brasileira 35(11):906-912. Departamento de Patologia Veterinária, Faculdade de Ciências Agrárias e Veterinárias, Universidade Estadual Paulista "Júlio de Mesquita Filho", Campus de Jaboticabal, Via de Acesso Prof. Paulo Donato Castellane s/n, Jaboticabal, SP 14884-900, Brazil. E-mail: rosevasc@fcav.unesp.br

Dendritic cells have attracted great interest from researchers as they may be used as targets of tumor immune evasion mechanisms. The main objective of this study was to evaluate the relationship between the dendritic cells (DCs) subpopulation in simple type mammary carcinomas in female dogs. Two groups of samples were used: the control group consisted of 18 samples of mammary tissue without changes and the tumor group with 26 simple type mammary carcinomas. In these groups, we evaluated the immunodetection of immature and mature myeloid DCs, plasmacytoid DCs and MHC-II. In mammary tumor, mature myeloid DCs predominated in the peritumoral region, while immature myeloid DCs and plasmacytoid DCs were evident in the intratumoral region. Immunostaining of MHC-II was visualized in mammary acini (control group), in tumor cells and inflammatory infiltration associated with tumors. The comparison between the control and tumor groups showed a statistically significant difference between immature myeloid DCs, mature myeloid DCs and plasmacytoid DCs. The immunodetection of MHC-II was not significant when comparing the groups. The predominance of immature DCs in the tumor group is possibly related to an inefficient immune response, promoting the development and survival of tumor cells. The presence of plasmacytoid DCs in the same group suggests a worse prognosis for female dogs with mammary tumors. Therefore, the ability of differentiation of canine dendritic cells could be influenced by neoplastic cells and by the tumor microenvironment.
\end{abstract}

INDEX TERMS: Dogs, antigen presenting cells, immune evasion, immunohistochemistry, mammary tumor.

RESUMO.- [Imunodetecção de células dendríticas mieloides e plasmocitoides nos carcinomas mamários em cadelas.] As células dendríticas têm despertado grande interesse dos pesquisadores, pois podem ser alvo dos me-

\footnotetext{
${ }^{1}$ Received on June 30, 2015.

Accepted for publication on September 15, 2015.

${ }^{2}$ Departamento de Patologia Veterinária, Faculdade de Ciências Agrárias e Veterinárias (FCAV), Universidade Estadual Paulista (Unesp), Via de Acesso Prof. Paulo Donato Castellane s/n, Jaboticabal, SP 14884-900, Brazil. *Corresponding author: rosevasc@fcav.unesp.br

${ }^{3}$ Instituto Federal do Norte de Minas Gerais (IFNMG), Campus Salinas, Fazenda Varginha, Km 2, Rodovia Salinas-Taiobeiras, Salinas, MG 39360000, Brazil.
}

canismos de evasão imune do tumor. 0 objetivo principal deste estudo foi avaliar a relação entre as subpopulações de células dendríticas (DCs) nos carcinomas mamários do tipo simples em cadelas. Dois grupos de amostras foram

\footnotetext{
${ }^{4}$ Faculdade Integrado de Campo Mourão, Rodovia BR-158 Km 207, Campo Mourão, PR 87300-970, Brazil.

${ }^{5}$ Universidade de Franca (Unifran), Hospital Veterinário, Av. Dr. Armando Salles Oliveira 201, Pq. Universitário, Franca, SP 14404-600, Brazil.

${ }^{6}$ Departamento de Clínica, Cirurgia e Reprodução Animal, Faculdade de Medicina Veterinária (FMVA), Unesp, Campus de Araçatuba, Rua Clóvis Pestana 793, Araçatuba, SP 16050-680, Brazil.

${ }^{7}$ Departamento de Ciências Exatas, FCAV-Unesp, Via de Acesso Prof. Paulo Donato Castellane s/n, Jaboticabal, SP 14884-900, Brazil.
} 
utilizados, o grupo controle composto por 18 amostras de tecido mamário sem alterações e o grupo tumor com 26 carcinomas mamários do tipo simples. Nestes grupos foram avaliadas a imunodetecção de DCs mieloides imaturas e maduras, DCs plasmocitoides e de MHC-II. Nas mamas com tumor, as DCs mieloides maduras predominaram na região peritumoral, enquanto que as DCs mieloides imaturas e as DCs plasmocitoides foram evidentes na região intratumoral. A imunomarcação do MHC-II foi visualizada nos ácinos mamários (grupo controle), nas células tumorais e no infiltrado inflamatório associado aos tumores. Na comparação entre os grupos controle e tumor houve diferença estatística significativa entre as DCs mieloides imaturas, DCs mieloides maduras e DCs plasmocitoides. A imunodetecção de MHC-II não foi significativa na comparação entre os grupos. A predominância de DCs imaturas no grupo tumor, possivelmente, está relacionada com uma resposta imune ineficiente, favorecendo o desenvolvimento e a sobrevivência das células tumorais. A presença das DCs plasmocitoides no mesmo grupo sugere um prognóstico pior para cadelas com tumores de mama. Portanto, a capacidade de diferenciação das células dendríticas caninas poderia ser influenciada pelas células neoplásicas e pelo microambiente tumoral.

TERMOS DE INDEXAÇÃO: Cães, células apresentadoras de antígeno, evasão imune, imuno-histoquímica, neoplasia de mama.

\section{INTRODUCTION}

The interest in researching the relationship between tumor antigens and the immune system is still the focus in research aimed at elucidating pro- and anti-tumor mechanisms. The understanding of cellular immunity arose in the mid-20th century (Maldonado-López \& Moser 2001). In the 60s and 70s, the researchers Steinman and Cohn (Steinman 2012) discovered a new population of cells, called dendritic cells (DCs), which became important in understanding the mechanisms of antigen presentation (Hart 1997).

DCs are a group of very heterogeneous leukocytes and this diversity depends on precursor populations, the anatomical location, the function and of their stage of maturation, which influence the immune response. In recent years, many attempts have been carried out in order to sort the subsets of DCs by phenotypic and functional analysis. Until 2000 there was not yet a complete model established for humans (Banchereau et al. 2000), currently some progress has been made both for human (Liu \& Nussenzweig 2010) and for mice DCs (Ardavín et al. 2001).

There are different subpopulations of DCs with phenotypical and functional characteristics that vary according to their location (Ardavín et al. 2001). In humans, they are derived from CD34 + pluripotent stem cells in the bone marrow. Its differentiation follows through myeloid and lymphoid pathways. The latter appear to a lesser extent in the organism (Banchereau \& Steinman 1998, Gogolák et al. 2003, Cruvinel et al. 2010). These lineages are differentiated by the myeloid marker CD11c. Myeloid DCs have CD11c + / CD123- staining, while lymphoid are CD11c-/ CD123+ (Pulendran et al. 1999).
DCs are specialized in processing and presenting antigens and making the connection between the innate and adaptive immune responses (Hart 1997, Banchereau \& Steinman 1998, Kah-Wai et al. 2006). However, when exposed to a tumor environment, DCs can present functional failure, caused by the direct influence of the tumor. It is believed that this failure is one of the main causes which culminate in tumor escape (Kah-Wai et al. 2006).

Maturation of DC controls the initiation of the immune response. However, the influence on the maturation of DC can lead to immune tolerance by inducing Th2 response. As a result there is a reduction of the phenotype of mature and functionally competent DCs, resulting in an inability to initiate a specific immune response against the tumor. In contrast, a greater number of immature and functionally incompetent DCs induce tolerance of T lymphocytes and thus tumor escape of DCs surveillance (Gabrilovich 2004, Kah-Wai et al. 2006).

Recent studies in humans with lung and breast cancer showed a significant decrease in populations of mature DCs. DCs from peripheral blood of these patients expressed lower levels of MHC II and co-stimulatory molecules, which indicated a failure in the activation. The understanding of the relationship between functional impairment of DCs and tumor progression is clinically important, but its mechanisms are still unclear. The production of tumor derived factors may induce failure in the differentiation and maturation of DCs. Among these are cytokines and tumor-derived growth factors that have pro-tumor activity, such as VEGF, M-CSF, IL-6, GM-CSF, IL-10 and TGF- $\beta$ (Kah-Wai et al. 2006).

In veterinary oncology literature few reports exist on the role of DCs in tumors, particularly in mammary gland tumors, one of the most frequently diagnosed in this species. Understanding the involvement of these cells in canine mammary carcinomas will contribute to comprehending the mechanisms of tumor immune escape for future studies of antineoplastic therapy. The aim of this study was to determine the density of immature and mature myeloid DCs and plasmacytoid DCs, through immunohistochemistry, in canine mammary carcinomas.

\section{MATERIALS AND METHODS}

In this study 26 samples of mammary gland tumor were used from 21 female dogs which were treated by the Veterinary Oncology Services and Obstetrics and Animal Reproduction of the "Governador Laudo Natel" Veterinary Hospital (FCAV-Unesp, SP, Brazil). Only samples of simple type mammary carcinomas (tumor group) were selected as described by Cassali et al. (2011) and classified as tubular, papillary and solid carcinoma. The grade of malignancy of the tumors was based on Elston and Ellis (1998). For the control group, 18 samples of tumor-free mammary glands of dogs (control group) that were necropsied at the Veterinary Pathology Department at the same institution were used. The occurrence of regional lymph node metastasis was analyzed. Fragments were collected for fixation in formaldehyde (10\%) and freezing (liquid nitrogen) for histopathological and immunohistochemical analyses. The design for this study was approved by the Ethics and Animal Welfare Committee (CEUA no 014526/12), of FCAV / UNESP, Jaboticabal, State of São Paulo, Brazil. 


\section{Immunohistochemical method}

The antibodies, dilution and antigen retrieval used for the immunohistochemical analysis were described in Table 1. The immunohistochemical protocol used for paraffin samples (CD83, CD123 and MHC-II) consisted of: to block the endogenous peroxidase ( $8 \%$ solution of methanol and 30 volumes of hydrogen peroxide) and the block non-specific reactions (serum-free Protein Block, code X0909, DAKO Corp., Carpinteria, CA) incubation took place for 30 minutes in a humidity chamber at room temperature. The chromogen was DAB (3,3-diaminobenzidine, code K3468-1, DAKO Corp., Carpinteria, CA) and counter-staining was Harris Hematoxylin.

Table 1. Antibodies used to dendritic cell and MHC-II immunostaining in canine mammary glands with and without neoplasia

\begin{tabular}{|c|c|c|c|c|c|}
\hline Antibodies & Brand & Cell-type & $\begin{array}{l}\text { Antigen } \\
\text { recovery }\end{array}$ & $\begin{array}{c}\text { Dilution of } \\
\text { primary } \\
\text { antibody** }^{*}\end{array}$ & Substrate \\
\hline $\begin{array}{c}\text { CD11 } c^{*} \\
\text { (mouse anti-dog, } \\
\text { monoclonal) } \\
\text { Clone CA11.6A1 }\end{array}$ & $\begin{array}{l}\text { ABD Serotec } \\
\quad \text { (code } \\
\text { MCA1778S) }\end{array}$ & $\begin{array}{l}\text { Immature } \\
\text { myeloid DCs }\end{array}$ & - & 1:900 & $\begin{array}{c}\text { Advance }{ }^{\text {(Dako) }}\end{array}$ \\
\hline $\begin{array}{c}\text { CD83 } \\
\text { (mouse anti- } \\
\text { human } \\
\text { monoclonal) } \\
\text { Clone 1H4b }\end{array}$ & $\begin{array}{l}\text { Abcam } \\
\text { (code } \\
\text { ab49324) }\end{array}$ & $\begin{array}{c}\text { Mature } \\
\text { myeloid DCs }\end{array}$ & $\begin{array}{c}\text { Water bath } \\
97^{\circ} \mathrm{C}\end{array}$ & 1:100 & $\begin{array}{c}\text { Advance } \\
\text { (Dako) }\end{array}$ \\
\hline $\begin{array}{l}\text { CD123 } \\
\text { (rabbit anti- } \\
\text { human, } \\
\text { policlonal) }\end{array}$ & $\begin{array}{c}\text { Abcam } \\
\text { (code } \\
\text { ab154402) }\end{array}$ & $\begin{array}{c}\text { Plasmacytoid } \\
\text { DCs }\end{array}$ & $\begin{array}{l}\text { Steamer } \\
\text { (Pascal, } \\
\text { DAKO) }\end{array}$ & 1:400 & $\begin{array}{l}\text { Mach-4C) } \\
\text { (Biocare) }\end{array}$ \\
\hline $\begin{array}{l}\text { Anti-HLA-DR } \\
\text { (mouse anti- } \\
\text { human, } \\
\text { monoclonal) } \\
\text { Clone TAL.1B5 }\end{array}$ & $\begin{array}{c}\text { Dako } \\
\text { (code } \\
\text { M0746) }\end{array}$ & MHC-II & $\begin{array}{c}\text { Water bath } \\
97^{\circ} \mathrm{C}\end{array}$ & $1: 500$ & $\begin{array}{c}\text { Advance } C \\
\text { (Dako) }\end{array}$ \\
\hline
\end{tabular}

* Frozen section, ${ }^{* *}$ Incubation time of the primary antibody $=18$ horas.

The immunohistochemical protocol used for marking CD11c (immature myeloid DCs) used $5 \mu \mathrm{m}$ thick frozen sections obtained with a cryostat (Minotome - Damon/IEC Division). The sections were fixed in acetone $\left(-20^{\circ} \mathrm{C} / 10\right.$ minutes $)$ and following steps identical to that of paraffin-embedded tissues.

The positive control tissues used for the antibodies CD123, CD83, and HLA-DR (MHC-II) were as recommended by the manufacturer. For CD11c antibody was used canine tonsil tissue as the positive control. As the negative control antibody diluent (Antibody diluent with background Reducing components, DAKO Corp., Carpinteria, CA, cod. S3022) was used, replacing the primary antibody, for all assays.

\section{Follow-up analysis}

For the tumor group, female dogs that survived or died from mammary gland tumor were evaluated. The follow-up was carried out for an average period of one year and a half after the completion of mastectomy in order to evaluate recurrence or metastasis. Of the 21 female dogs with mammary tumor in this study, it was possible to obtain information from the owners of only 17 studied dogs. Overall survival was evaluated by Kaplan-Meier estimated survival curves.

\section{Statistical analysis}

The counting of immunostained cells with CD11c, CD83, CD123 and MHC-II was carried out using a light microscope (Ni- kon Eclipse E200) for both the control group and tumor group. For quantification five fields were chosen at random $(40 \mathrm{x}$ objective lens), where the marked cells were counted in an area of $0.19625 \mathrm{~mm}^{2}$.

The counting of immunomarked subpopulations of DCs (CD11c, CD83, CD123) and MHC-II were subject to analysis of variance (ANOVA) and the comparison between means was performed by parametric test Student Newman Keuls (SNK). The frequency of plasmacytoid DCs immunostaining (CD123) in animals with mammary tumors and animals without mammary tumors were analyzed. The relationship between plasmacytoid DCs with the histological type of the tumor was always analyzed in both groups by means of the Fisher exact test. The independence between variables was determined by the same test. Statistical analyses were conducted using the SAS software (SAS 9.1, SAS Institute, Cary, NC, USA), considering $\mathrm{P}<0.05$. The grade of malignancy of tumors was not considered in the analysis of variance, since there were no representative figures of all the grades when separated into groups.

\section{RESULTS}

Regarding the macroscopic examination of the tumors, the average size of the nodules was three centimeters, none of these cases had regional lymph node metastasis at the time of tumor diagnosis. Tumors were classified histologically in carcinomas type tubular, papillary and solid (Table 2).

Table 2. Canine mammary tumors classified by their histological type and grade of malignancy

\begin{tabular}{lcc}
\hline Histological type & Grade & Number of cases \\
\hline Tubular carcinoma & 1 & 11 \\
& 2 & 3 \\
Papillary carcinoma & 3 & 3 \\
Solid carcinoma & 1 & 4 \\
& 2 & 2 \\
Total & 2 & 1 \\
& 3 & 2 \\
\end{tabular}

From the 17 female dogs subject to follow-up, nine are alive (53\%) and eight of them died (47\%), until 18 months after tumor diagnosis. Metastasis represented $67 \%$ of the causes of death in dogs and it was found in the oral cavity, lung and urinary bladder. The other causes of death were related to trampling $(n=2)$ and cardiac arrest $(n=1)$, totaling $33 \%$.

The immunostaining of immature myeloid DCs (CD11c antibody) was cytoplasmic and these cells showed moderate cytoplasmic size with few cytoplasmic projections similar to dendrites and rounded nuclei. Immature DCs were found, mostly between tumor cells (intratumoral / Fig.1A) and rarely associated with tumor stroma. There was a significant difference ( $p<0.0001$, SNK test) for CD11c marking between control and tumor groups, with the highest average in the tumor group (Fig.1B).

The detection of mature myeloid DCs (CD83) was cytoplasmic and they appeared in greater proportion, in the tumor stroma (Fig.1C). The comparison between control and tumor groups showed significant difference $(p<0.00198$, SNK test), with the highest average in the tumor group (Fig.1D). 

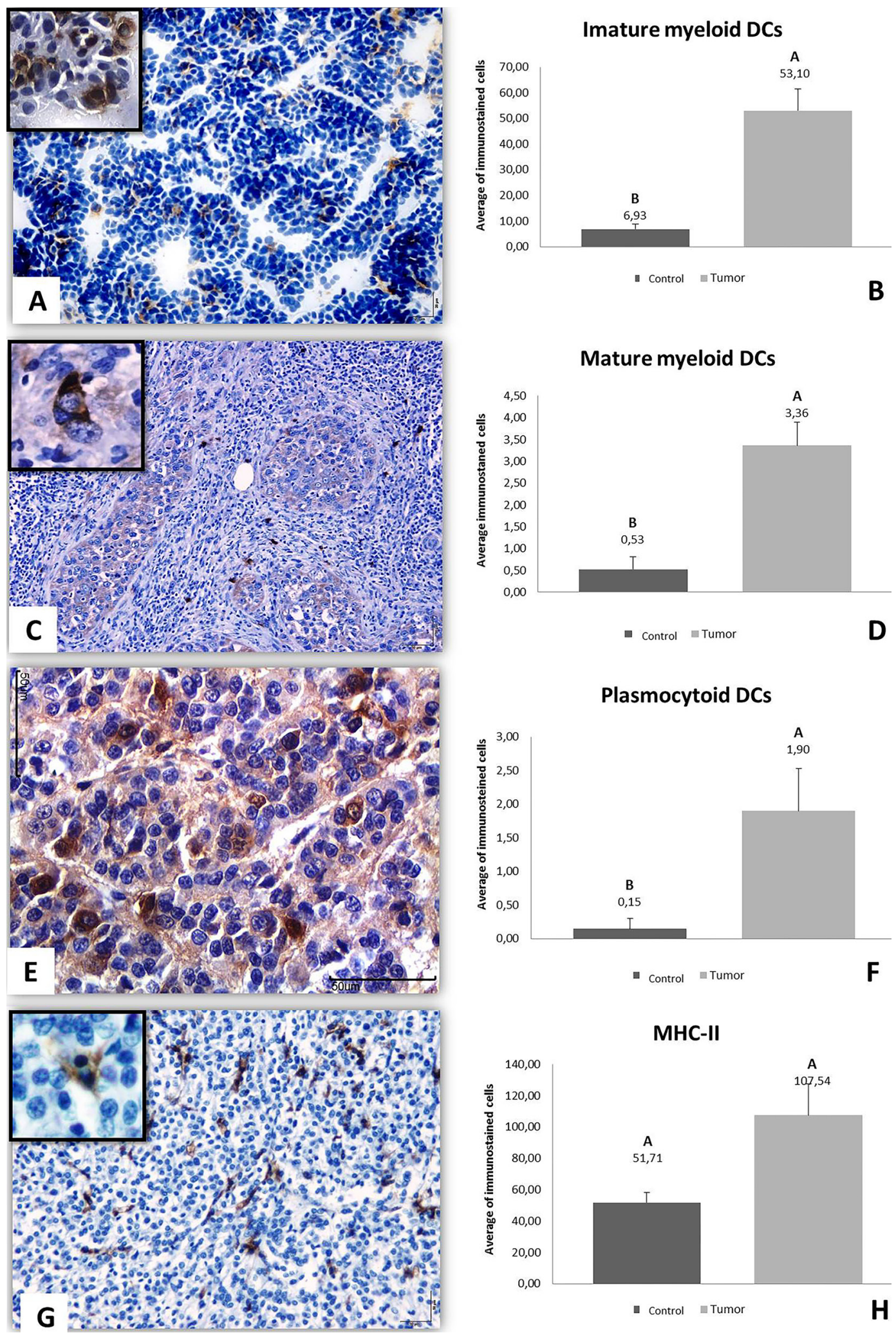

Fig.1. Immunohistochemistry of canine mammary carcinomas. (A) Marking of immature myeloid DCs (CD11c) in a grade I tubular carcinoma (bar $=50 \mu \mathrm{m} /$ detail). (B) Note that the means of immature myeloid DCs differ among the studied groups ( $<<0.0001)$. (C) Mature myeloid DCs (CD83) in the peritumoral region of a grade III tubular carcinoma (bar=100 $\mu$ m). In detail, a mature DC. (D) Verification of significant differences between the control and tumor groups for mature myeloid DCs (p<0.0198). (E) Marking of the plasmacytoid DCs in a grade III tubular carcinoma (bar=50 $\mu \mathrm{m})$. (F) Average of plasmacytoid DCs was significantly higher in the tumor group $(p<0,0214)$. (G) Immunomarking of the MHC-II in a grade III tubular carcinoma (bar=50 $\mu \mathrm{m} /$ detail). (H) Immunomarking of MHC-II did not differ significantly among the groups studied $(p<0,0593)$. Means and standard errors of immunomarking (Fig.B, D, F, H/Student Newman Keuls Test). Complex peroxidase-linked polymers (Fig.A, C, E, F, G). 
The marking of plasmacytoid DCs (CD123 antibody) was cytoplasmic. They were located predominantly in the intratumoral area (Fig.1E) and in a smaller proportion in the mononuclear inflammatory infiltration. Significant difference $(\mathrm{p}<0.0214$, SNK test) was observed between the control and tumor groups, with the highest average in the tumor group (Fig.1F). When compared to the histological types, the plasmacytoid DCs media was 20.6 (tubular), 18.4 (papillary) and 6.4 (solid). No significant difference was observed between histologic types of tumor $(\mathrm{p}=3679)$.

MHC-II (HLA-DR) immunodetection was predominantly cytoplasmic and occurred in acini of mammary gland cells, in tumor cells (Fig.1G) or in the adjacent inflammatory infiltration to the tumor. There was no significant difference ( $p<0.0593$, SNK test) between the control and tumor groups (Fig.1H).

The frequency of immunostaining for plasmacytoid DCs (CD123) in animals affected or not by mammary gland tumor was significant (Fisher's exact test, $\mathrm{p}<0.0019$ ) between the groups. The tumor group showed higher frequency in the immunodetection of this cell type (19/26), compared with the control group (1/18). This result showed that there is a significant relationship between the presence of plasmacytoid DCs and mammary tumor. The frequency of plasmacytoid DCs immunostaining was also significant (Fisher's exact test, $\mathrm{p}<0.0080$ ) relative to histologic types tubular $(12 / 17)$, papillary $(5 / 6)$ and solid $(2 / 3)$, where compared to the control group without tumor $(1 / 18)$. These results confirmed a relationship of dependency between the presence of plasmacytoid DCs and tumor histological type. The overall survival analysis showed that the dogs with tubular carcinoma had lowest survival time than solid and papillary carcinoma after 15 months of the mastectomy (Fig.2).

\section{DISCUSSION}

The mean volume of mammary tumors was three centimeters, which is consistent with the findings of Queiroga \& Lopes (2002) who reported that the majority of malignant tumors have an average size which ranges from three to five centimeters. However, the size of the mammary lump

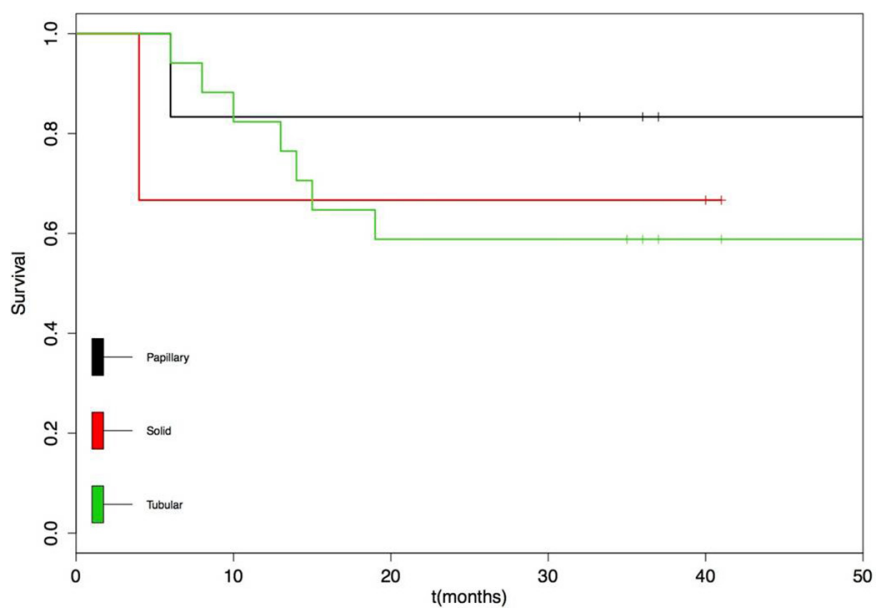

Fig.2. Overall survival analysis of canine mammary carcinomas (3 solid carcinomas; 6 papillary carcinomas; 17 tubular carcinomas). Kaplan-Meier Estimate. can be influenced by the stage of the estrous cycle (Fonseca \& Daleck 2000). In relation to samples from the tumor group, no lymph nodes examined in stage histological diagnosis of the tumors showed foci of micrometastases. Chang et al. (2005) observed that dogs with lymph node metastasis usually have tumors larger than five centimeters. This point coincides with the observations of this study.

The histological types of mammary carcinomas had a large variation in the number of samples for each group. In plasmacytoid DCs count was found that the tubular carcinoma had the highest mean, but without significant differences between groups. The bitches with mammary tumors had a higher density of plasmacytoid DCs compared to the control group. The females with tubular carcinoma had shorter survival time after tumor diagnosis. This suggests that plasmacytoid DCs may be contributing to the greater aggressiveness of these tumors resulting in death associated with tumor progression. In other studies involving the survival time of cancer patients, the dogs with tubular carcinoma grade III had lower survival time (Frehse et al., 2014), results similar to those obtained in our study. Nunes et al. (2014) and Estrela-Lima et al. (2014) also observed decreased survival time for the same histological type, together with other most aggressive types such as carcinosarcoma.

The immunostaining of immature and mature myeloid DCs were significantly higher in the tumor group compared to the control group. This difference suggests possible tumor activity on the maturation of DCs. Previous studies suggest that when exposed to a tumor microenvironment, DCs can present functional failure, such as low $\mathrm{T}$ lymphocytes stimulation capacity due to poor expression of costimulatory molecules (Bell et al. 1999). The maturation of DCs is critical for triggering the immune response. Defects in this process can lead to reduction of mature, functionally competent DCs and an increase in the immature DCs associated with the tumor microenvironment. The prevalence of the latter may induce tolerance of $\mathrm{T}$ lymphocytes and tumor escape from DCs surveillance (Gabrilovich 2004, Kah-Wai et al. 2006).

The location of immature DCs predominated in the intratumoral environment, coinciding with reports done by Bell et al. (1999) who observed the compartmentalization of this subpopulation of DCs among the cells of breast carcinoma in women. Mature DCs were confined to the peritumoral region of canine carcinomas. These results differ from reports by Sandel et al. (2005), who observed mature DCs in the intratumoral region of human colorectal tumor. According to Bell et al. (1999), this compartmentalization of human myeloid DCs could indicate that stromal factors may determine the adhesion of the DCs, since physiologically mature DCs are only observed in lymphoid organs, where they interact intimately with $\mathrm{T}$ lymphocytes. This author suggest that it is related to an immune response which is specific to the tumor. In the case of canine carcinomas, this protective role of mature DCs seems not to take place, since the number of immunostained cells for this phenotype was very low when compared to immature DCs, even within the tumor group. 
The anti-CD83 antibody was chosen for the marking of mature DCs in this study because there are few reports which show the application of this marker for mature DCs in veterinary medicine (Qeska et al. 2013) different to what happens with tumors in humans (Aerts-Toegaert et al. 2007, Lechmann et al. 2008). Poindexter et al. (2004) reported that CD83 is a marker that has been shown to be effective in identifying mature DCs in human tumors. According to Cao et al. (2005) during the maturation of human DCs, the kinetics of induction of surface CD83 is faster than that of CD40, CD80 and CD86 when exposed to LPS (lipopolysaccharide), and thus being an efficient marker of mature DCs. In the present study, it is suggested that CD83 was a marker of mature DCs in canine tissues.

With regard to the MHC-II, no statistically significant difference between the control group and the tumor in relation to the expression of MHC-II molecule was observed. The MHC plays an important role in several types of immune reactions due to their involvement in antigen presentation to T lymphocytes. MHC class I is expressed in all cell types, whereas the MHC class II types is limited to specific cells such as macrophages, B lymphocytes and antigen presenting DCs, among them tumor antigens (Warabi et al. 2000). In this study, inefficient expression of MHC-II was characterized by its immunodetection in the cytoplasm of inflammatory and neoplastic cells, which could explain the inability of antigen presentation to T lymphocytes. Likewise, the lower amount of mature DCs in comparison to immature DCs may also be related, since only the mature DCs can express MHC molecules on their cell membrane. In the literature it is emphasized that the increase of IL-10 (Th2 response) can lead to the decreased expression of MHC II in the early stages of the immune response, contributing to the inhibition of $\mathrm{T}$ cell activation (Abbas \& Lichtman 2007).

Some authors claim that the intratumoral infiltration of myeloid DCs may influence the prognosis of breast tumors in women (Iwamoto et al. 2003). However, the infiltration of myeloid DCs within breast carcinoma in women may not be a prognostic factor, as according to Treilleux et al. (2004), the infiltration of plasmacytoid DCs has to do with a low survival rate. In the present study, a significant dependency between the presence of plasmacytoid DCs and mammary tumor in female dogs was confirmed, as well as with the histological type of the tumor. This dependence suggests that plasmacytoid DCs were more frequent in mammary gland with tumors and in the most aggressive histological types of mammary carcinomas.

\section{CONCLUSIONS}

There is a relationship between the presence of immature myeloid DCs and malignant tumors in female dogs, suggesting one of mechanisms of immune evasion by tumor cells.

The intratumoral location of immature myeloids DCs suggests a close relationship between this cell type and neoplastic cells.

The plasmacytoid DCs in the tumor site are indicative of poor prognosis in dogs with mammary tumor.
Acknowledgements.- Financial assistance was provided by FAPESP (Fundação de Amparo à Pesquisa do Estado de São Paulo; Procedural number 2012/09385-0). Mayara C. Rosolem was supported by a grant from FAPESP (Procedural number 2011/03510-4). The authors wish to acknowledge Mrs. Francisca A. Ardisson for her histotechnical assistance.

Conflict of interest.- The authors declare that they have no conflict of interest.

\section{REFERENCES}

Abbas A.K. \& Lichtman A.H. 2007. Reconhecimento antigênico no sistema imune adaptativo, p.69-90. In: Ibid. (Eds), Imunologia Básica: funções e distúrbios do sistema imunológico. Elsevier Brasil, Rio de Janeiro.

Aerts-Toegaert C., Heirman C., Tuyaerts S., Corthals J., Aerts J.L., Bonehill A., Thielemans K. \& Breckpot K. 2007. CD83 expression on dendritic cells and T cells: correlation with effective immune responses. Eur. J. Immunol. 37:686-695

Ardavín C., Del Hoyo G.M., Martín P., Anjuère F., Arias C.F., Marín A.R., Ruiz S., Parrillas V. \& Hernández H. 2001. Origin and differentiation of dendritic cells. Trends Immunol. 22:691-700.

Banchereau J. \& Steinman R.M. 1998. Dendritic cells and the control of immunity. Nature 392:245-252.

Banchereau J., Briere F., Caux C., Davoust J., Lebecque S., Liu Y.J., Pulendran B. \& Palucka K. 2000. Immunobiology of dendritic cells. Annu. Rev. Immunol. 18:767-811.

Bell D., Chomarat P., Broyles D., Netto G., Harb G.M., Lebecque S., Valladeau J., Davoust J., Palucka K.A. \& Banchereau J. 1999. In breast carcinoma tissue, immature dendritic cells reside within the tumor, whereas mature dendritic cells are located in peritumoral areas. J. Exp. Med. 190:14171425.

Cao W., Lee S.H. \& Lu J. 2005. CD83 is preformed inside monocytes, macrophages and dendritic cells, but it is only stably expressed on activated dendritic cells. Biochem. J. 385:85-93.

Cassali G.D., Lavalle G.E., De Nardi A.B., Ferreira E., Bertagnolli A.C., Lima A.E., Alessi A.C., Daleck C.R., Salgado B.S., Fernandes C.G., Sobral R.A., Amorim R.L., Gamba C.O., Damasceno K.A., Auler P.A., Magalhães G.M., Silva J.O., Raposo J.B., Ferreira A.M.R., Oliveira L.O., Malman C., Succari D.A.P.C., Tanaka N.M., Ribeiro L.R., Campos L.C., Souza C.M., Leite J.S., Soares L.M.C., Cavalcanti M.F., Fonteles Z.G.C., Ichuch I.D., Paniago J., Oliveira T.S., Terra E.M., Castanheira T.L.L., Felix A.O.C., Carvalho G.D., Guim T.N., Garrido E., Fernandes S.C., Maia F.C.L., Dagli M.L.Z., Ocha N.S.R., Grandi F., Machado J.P., Silva S.M.M.S., Bezerril J.E., Frehse M.S. \& Almeida E.C.P. 2011. Consensus for the diagnosis, prognosis and treatment of canine mammary tumors. Braz. J. Vet. Pathol. 4:153-180.

Chang S., Chang C., Chang T. \& Wong M. 2005. Prognostic factors associated with survival two years after surgery in dogs with malignant mammary tumors: 79 cases (1998-2002). J. Am. Vet. Med. Assoc. 227:1625-1629.

Cruvinel W.M., Mesquita Júnior D., Araújo J.A.P., Catelan T.T.T., Souza A.W. S., Silva N.P. \& Andrade L.E.C. 2010. Sistema imunitário - parte I - fundamentos da imunidade inata com ênfase nos mecanismos moleculares e celulares da resposta inflamatória. Revta Bras. Reumatol. 50:434-461.

Estrela-Lima A., Costa Neto J.M., Oriá A.P., Moreira E.L.T., Peixoto T.C., Muramoto C., D’Assis M.J.M.H., Vieira Filho C.H.C., Machado M.C.A., Nascimento N.A., Silva D.N., Martins Filho E.F., Gomes E.A., Silva L.P., Requião L.G.T. \& Fontes T.N. 2014. Clinical pathological study of mammary tumors in female dogs from the veterinary hospital of UFBA - Bahia, Brazil. Braz. J. Vet. Pathol. 7:126-130.

Elston C.W. \& Ellis I.O. 1998. Assessment of histological grade, p.365-384. In: Ibid. (Eds), Systemic Pathology: the breast. Churchill and Livingstone, London.

Fonseca C.S. \& Daleck C.R. 2000. Neoplasias mamárias em cadelas: influência hormonal e efeitos da ovário-histerectomia como terapia adjuvante. Ciência Rural 30:731-735.

Frehse M.S., Bracarense A.P.F.R.L., Di Santis G.W., Da SIlva E.O., Freire R.L., Machado M.A. \& Martins M.I.M. 2014. Epidemiological and histological aspects of canine mammary tumors diagnosed at the Veterinary Teaching Hospital/UEL. Braz. J. Vet. Pathol. 7:118-122. 
Gabrilovich D. 2004. Mechanisms and functional significance of tumour induced dendritic-cell defects. Nat. Rev. 4:941-952.

Gogolák P., Réthi B., Hajas G. \& Rajnavölgyi E. 2003. Targeting dendritic cells for priming cellular immune responses. J. Mol. Recognit. 16:299-317.

Hart D.N.J. 1997. Dendritic cells: unique leukocyte populations which control the primary immune response. Blood 90:3245-3287.

Iwamoto M., Shinohara H., Miyamoto A., Okuzawa M., Mabuchi H., Nohara T., Gon G., Toyoda M. \& Tanigawa N. 2003. Prognostic value of tumor-infiltrating dendritic cells expressing CD83 in human breast carcinomas. Int. J. Cancer 104:92-97.

Kah-Wai L., Jacek T. \& Jacek R. 2006. Dendritic cells heterogeneity and its role in cancer immunity. J. Cancer Res. Ther. 2:35-40.

Lechmann M., Shuman N., Wakeham A. \& Mak T.W. 2008. The CD83 reporter mouse elucidates the activity of the CD83 promoter in $\mathrm{B}, \mathrm{T}$, and dendritic cell populations in vivo. PNAS 105:11887-11892.

Liu K. \& Nussenzweig M.C. 2010. Origin and development of dendritic cells. Immunol. Rev. 234:45-54.

Maldonado-López R. \& Moser M. 2001. Dendritic cell subsets and the regulation of Th1/Th2 responses. Seminars Immunol. 13:275-292.

Nunes F.C., Gamba C.O., Damasceno K.A., De Campos C.B., Horta R.S., De Araújo M.R., Monteiro L.N., Lavalle G.E., Ferreira E. \& Cassali G.D. 2014. Analysis of clinicopathological data, therapeutical conduct and overall survival of canine mammary lesions attended at the Veterinary Hospital of the Federal University of Minas Gerais (UFMG). Braz. J. Vet. Pathol. 7:122-126p.

Poindexter N.J., Sahin A., Caça K.K. \& Grimm E.A. 2004. Analysis of dendri- tic cells in tumor-free and tumor-containing sentinel lymph nodes from patients with breast cancer. Breast Cancer Res. 6:408-405.

Pulendran B., Smith J.L., Caspary G., Brasel K., Pettit D., Maraskovsky E. \& Maliszewski C.R. 1999. Distinct dendritic cell subsets differentially regulate the class of immune response in vivo. Proc. Natl Acad. Sci. USA 96:1036-1041.

Qeska V., Baumgärtner W. \& Beineke A. 2013. Species-specific properties and translational aspects of canine dendritic cells. Vet. Immunol. Immunopathol. 151:181-192.

Queiroga F. \& Lopes C. 2002. Tumores mamários caninos, pesquisa de novos fatores de prognóstico. RPCV 97:119-127.

Sandel M.H., Dadabayev A.R., Menon A.G., Morreau H., Melief C.J.M., Offringa R., Van der Burg S.H., Janssen-Van Rhijn C.M., Ensink N.G., Tollenaar R.A.E.M., Van De Velde C.J.H. \& Kuppen P.J.K. 2005. Prognostic value of tumor-infiltrating dendritic cells in colorectal cancer: role of maturation status and intratumoral localization. Clin. Cancer Res. 11:2576-2582.

Steinman R.M. 2012. Decisions about dendritic cells: past, present, and future. Annu. Rev. Immunol. 30:1-22.

Treilleux I., Blay J.Y., Bendriss-Vermare N., Ray-Coquard I., Bachelot T., Guastalla J.P., Bremond A., Goddard S., Pin J.J., Barthelemy-Dubois C. \& Lebecque S. 2004. Dendritic cell infiltration and prognosis of early stage breast cancer. Clin. Cancer Res. 10:7466-7474.

Warabi M., Kitagawa M. \& Hirokawa K. 2000. Loss of MHC class II expression is associated with a decrease of tumor-infiltrating $\mathrm{T}$ cells and an increase of metastatic potential of colorectal cancer: immunohistological and histopathological analyses as compared with normal colonic mucosa and adenomas. Pathol. Res. Pract. 196:807-815. 